\title{
Practical prediction of creep and shrinkage of high strength concrete
}

\author{
Zdeněk P. Bažant \\ Active member RILEM, Professor of Civil Engineering and Director, Center for Concrete and Geomaterials, \\ Technological Institute, Northwestern University, Evanston, Illinois 60201, U.S.A.
}

\section{Liisa Panula}

Principal Structural Engineer, TAMS, New York, NY 11003, U.S.A.

\begin{abstract}
Model for practical prediction of creep and shrinkage of normal strength concrete, developed previously, is extended to high strength concrete. It is found that only a minor adjustment for the concrete strength effect is needed in the formulas for drying creep. The formulas for basic creep and shrinkage need no adjustment. The prediction model is compared with test data for creep and shrinkage obtained recently by Ngab, Nilson and Slate, and by Collepardi, Corradi and Valente, and a satisfactory agreement is demonstrated. The coefficient of variation of the deviations from test data is not larger than that for the normal strength range. However, the existing data are rather limited and further testing is desirable.
\end{abstract}

\section{INTRODUCTION}

A comprehensive prediction model for creep and shrinkage of concrete applicable over a very wide range of conditions has been recently developed ([1], [2], [3]). This model is more involved than some other previous prediction models, but shows a distinctly better agreement with the existing test data ([1], [2], [4]) and is to a greater extent based on physical considerations [3]. This model, briefly known as the BP Model, has been developed for normal strength portland cement concretes of cylindrical strengths ranging from 3,000 to 7,500 psi. Due to the current increased use of high strength concretes, an extension of this model to strengths exceeding 10,000 psi is needed. Such an extension has now been made possible by the test data of Ngab, Nilson and Slate ([5], [6]) and Collepardi, Corradi and Valente [7], and is attempted here. However, since the presently available data are rather limited, this extension must be considered tentative.

\section{SHRINKAGE}

The data base for the previously developed formulas [1] included some data for normal concretes of a relatively high strength and rather low water-cement ratios (McDonald's data, up to strength 7,300 psi). Therefore, it is not too surprising that the previously developed BP formulas (equations 1-10 in reference [1]) are found to yield reasonable agreement with the new measurements by Ngab et al.; see the solid line in figure 1. In the description of these tests it was stated that the specimens were exposed to laboratory air, the relative humidity of which is, in the present calculations, considered to be $60 \%$. The data points in the figure, as well as the specimen strengths shown, represent averages of values from different batches (see Appendix A). However, the last few readings were not reported for all the three batches, and so the last few points shown do not represent the same averages as the preceding points.

Shrinkage data were also reported by Collepardi [7]. In their data, the shrinkage strains for 100 days drying duration were quite high compared to other data for the same type of mixture composition and specimen size. Also, in these tests the specimens were exposed to a drying environment (of relative humidity $65 \pm 5 \%$ ) after a longer than usual curing period of 28 days at a $95 \%$ relative humidity.

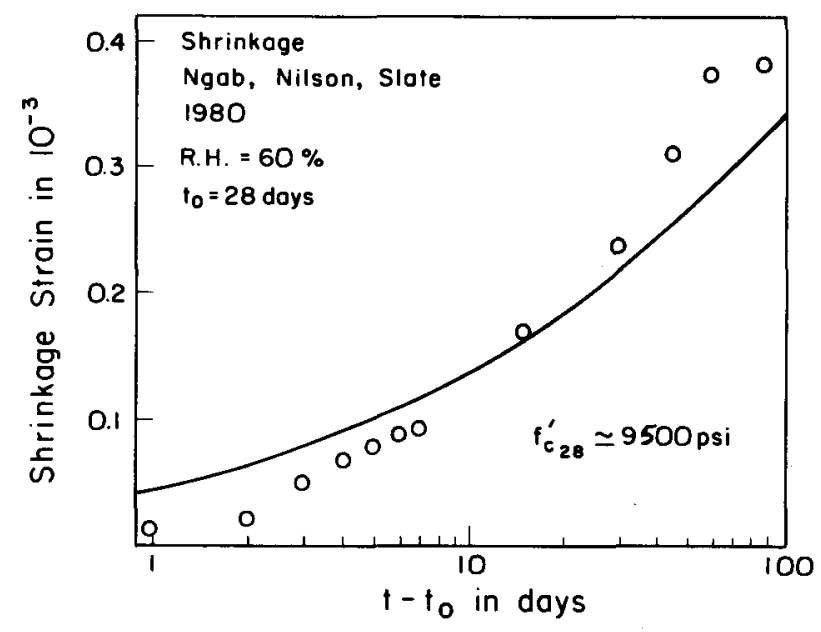

Fig. 1. - Comparison of theory (solid line) with Ngab, Nilson and Slate's test data for shrinkage. 


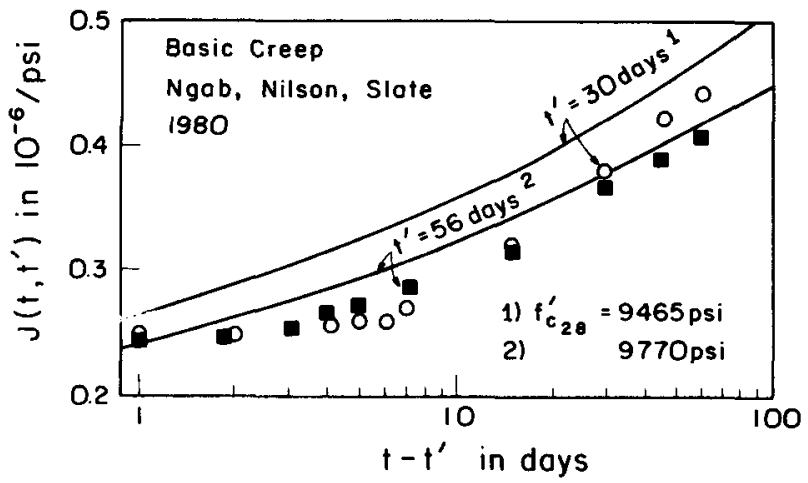

Fig. 2. - Comparison of theory (solid lines) with Ngab, Nilson and Slate's test data for basic creep.

\section{BASIC CREEP}

For basic creep, i. e. the creep at constant moisture content, the previously developed formulas (equations (11)-(19) of reference [1]) are also found to agree with the new test data reasonably well, with errors that are not larger than those previously determined within the normal strength range. This is demonstrated in comparison with the data of Ngab et al. in figure 2, in which the BP Model predictions are again shown by solid lines. Note that, in the reported measurements, the creep strain for the age of 56 days at loadings is higher at some creep durations than the creep strain reported for the age of $\mathbf{3 0}$ days at loading, which is contrary to the generally accepted aging effect. This is, however, explicable by normal scatter of measurements.

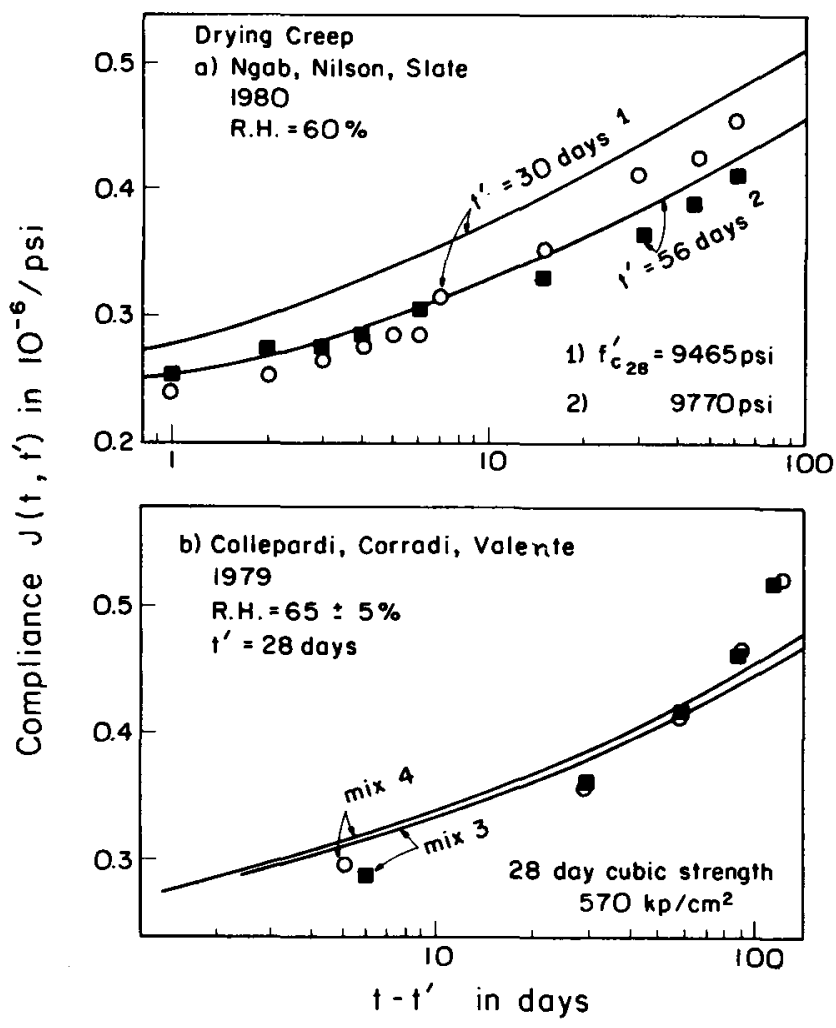

Fig. 3. - Comparison of theory (solid lines) with test data for drying creep by Ngab, Nilson and Slate and by Collepardi, Corradi and Valente.

\section{CREEP AT DRYING}

The previously reported formulas (eqs. (25)-(33) of reference 1) need a minor adjustment. Equations (26) and (28) of reference [1] need to be generalized as:

$\varphi_{d}^{\prime}=\left(1+\frac{t^{\prime}-t_{0}}{a_{d} \tau_{\mathrm{sh}}}\right)^{-1 / 2} \varphi_{d}$

where:

$a_{d}=10$ for $f_{c}^{\prime} \leqq 6,000 \mathrm{psi}$;

$a_{d}=1 \quad$ for $f_{c}^{\prime} \geqq 10,000 \mathrm{psi}$;

$\mathrm{S}_{d}\left(t, t^{\prime}\right)=\left(1+\mathrm{b}_{\mathrm{d}} \frac{\tau_{\mathrm{sh}}}{t-t^{\prime}}\right)^{c_{\mathrm{d}} n}$

where:

$b_{d}=10 \quad$ for $\quad f_{c}^{\prime} \leqq 6,000 \mathrm{psi} ;$
$b_{d}=100 \quad$ for $\quad f_{c}^{\prime} \geqq 10,000 \mathrm{psi}$.

Linear interpolation may be used for $a_{d}$ and $b_{d}$ between $f_{c}^{\prime}=6,000$ and $10,000 \mathrm{psi}$. In these formulas, $t_{0}=$ age at the start of drying, $t^{\prime}=$ age when constant stress is applied, $n$ is the exponent of double power law, $c_{d}$ is a correction coefficient given in Reference [1], $\tau_{s h}$ is the shrinkage-square half-time, proportional to the square of thickness of concrete, as indicated by diffusion theory; and $f_{c}^{\prime}=$ standard cylindrical strength at age of 28 days.

Drying creep calculated with these formulas is shown as the solid lines in figure 3 in comparison with the data of Ngab et al. and Collepardi et al. The data points from $\mathrm{Ngab}$ et al. represent again averages of their measurements (test series A-1, B-1, B-2).

Coefficient $\varphi_{d}^{\prime}$ adjusts the final drying creep value as a function of the delay of the start of loading after the start of drying, and function $S_{d}\left(t, t^{\prime}\right)$ gives the shape of drying creep curve. The adjustment in equations (1)-(4) means that, for high strength concretes as compared to normal strength concretes, the final drying creep value becomes smaller and the drying creep evolves slower. This trend is entirely reasonable if we assume that the mechanism of creep consists of some sort of diffusion or migration within the microstructure of the cement gel. In concretes of higher strengths, the pores are generally smaller and the passages between the larger (capillary) pores become longer. This suggests that diffusion phenomena should be slower and less pronounced.

The values of the conventional creep coefficient $\varphi\left(t, t^{\prime}\right)$, determined as indicated in reference [1] below equation (13), are calculated from prediction formula for creep compliance in table I for concrete of Ngab et al. It may be noted that the trend of the creep coefficient is similar to that shown in table II on p. 258 of reference [6].

\section{STATISTICAL EVALUATION}

Statistical characteristics of the deviations of the presently used data from the prediction formulas have 
TABLE I

CONVENTIONAL CREEP COEFFICIENT FOR CONCRETE: NGAB et al.

\begin{tabular}{|c|c|c|c|}
\hline $\begin{array}{c}t^{\prime} \\
\text { days }\end{array}$ & $\begin{array}{c}t-t^{\prime} \\
\text { days }\end{array}$ & $\begin{array}{c}\text { Basic } \\
\text { creep }\end{array}$ & $\begin{array}{c}\text { Drying } \\
\text { creep }\end{array}$ \\
\hline 30 & 100 & 1.44 & 1.43 \\
30 & 1,000 & 2.5 & 2.3 \\
56 & 100 & 1.24 & 1.42 \\
56 & 1,000 & 2.35 & 2.29 \\
\hline
\end{tabular}

been calculated in the same manner as defined by equations (62)-(65) in reference [1]. The results are listed in table II, in which $s$ represents the standard deviation, $\overline{\mathbf{J}}$ represents the mean of the data points, $\omega$ represents the coefficient of variation of observed deviations from the formulas; and subscript $j$ refers to the data series listed in table II. The overall coefficient of variation, $\bar{\omega}$, is calculated according to equation (64) of reference [1]. The coefficients of variation obtained in table II are acceptable, and in fact better than those obtained for a large number of concretes before (1).

TABLE II

STATISTICS OF THE DEVIATIONS OF HIGH STRENGTH CONCRETE MEASUREMENTS FROM PREDICTION FORMULAS

\begin{tabular}{|c|c|c|c|c|}
\hline & & $\mathbf{s}_{j}$ & $J_{j}$ & $\omega_{j}$ \\
\hline Collepardi et al. . . . & $\begin{array}{c}\text { Drying creep: } \\
t^{\prime}=30 \text { days } \\
\text { mix } 3 \\
\operatorname{mix} 4\end{array}$ & $\begin{array}{l}.036,4 \\
.034,12\end{array}$ & $\begin{array}{l}.359,3 \\
.364,1\end{array}$ & $\begin{array}{l}.101 \\
.093,7\end{array}$ \\
\hline Ngab et al. & $\begin{array}{c}\text { Shrinkage } \\
\text { Basic creep: } \\
t^{\prime}=30 \text { days } \\
t^{\prime}=56 \text { days } \\
\text { Drying creep: }\end{array}$ & $\begin{array}{l}.036,44 \\
.046,56 \\
.019,12\end{array}$ & $\begin{array}{l}.156,6 \\
.369,9 \\
.332,2\end{array}$ & $\begin{array}{l}.23 \\
.126 \\
.058\end{array}$ \\
\hline & $\begin{array}{l}t^{\prime}=30 \text { days } \\
t^{\prime}=56 \text { days }\end{array}$ & $\begin{array}{l}.041,15 \\
.013,62\end{array}$ & $\begin{array}{l}.383,8 \\
.339,7\end{array}$ & .107 \\
\hline
\end{tabular}

A simplified version of the BP Model, applicable over a more limited range of conditions, has also been developed [2]. Since that model is a special case, the present modifications for high strength concrete may be also applied for it.

\section{CONCLUSION}

To extend the validity of the previously developed BP Model to high strength concrete, only a minor adjustment in the prediction formula for drying creep is needed. Agreement with recently reported measurements is acceptable and no worse than that previously demonstrated for normal strength concretes. This conclusion, however, is based on rather limited data, and further testing of high strength concretes, involving a greater range of conditions, load durations, ages of loading, etc., is desirable.

\section{ACKNOWLEDGMENT}

Partial financial support of the work under U.S. National Science Foundation Grant No. CEE-8303148 is gratefully acknowledged.

\section{APPENDIX}

\section{Basic information on shrinkage and creep data used}

\section{Ngab, Nilson and Slate (1980) ([5] and [6])}

Prisms $3.5 \times 3.5 \times 10.5$ in $(89 \times 89 \times 267 \mathrm{~mm})$. Cement Type I, portland cement. A polymer-type, non-airentraining, water-reducing admixture, ASTM C494-71 Type A was used. Coarse aggregate-crushed limestone. Water-cement-sand-gravel ratio 1:0.32:1.23:1.58. Shrinkage and drying creep specimens, drying in lab air after 28 days of moist room curing. Relative humidity assumed as $60 \%$, and temperature as $21^{\circ} \mathrm{C}$. Shrinkage and drying creep data represent the average of test series A-1, B-1 and B-2 (swelling of shrinkage specimens in test series B-2 at early age is neglected). Specimens loaded at the age of 30 and 56 days. Stressstrength ratio 0.45 . A verage strengths of test specimens loaded at the age of 30 and 56 days are 9,060 and 10,150 psi. Corresponding 28-day cylinder strengths 9,465 and 9,770 psi were used.

\section{Collepardi, Corradi and Valente (1979 [7]}

Prisms $160 \times 160 \times 640 \mathrm{~mm}$, drying at $65 \pm 5 \%$ relative humidity after a curing period of 28 days at $95 \%$ humidity. Temperature $20^{\circ} \pm 1^{\circ} \mathrm{C}$. Cement type $\mathrm{V}, 350$ $\mathrm{kg} / \mathrm{m}^{3}$. Specimens loaded at the age of 28 days. Stressstrength ratio 0.3 . Mix 3: water-cement-sand-gravel ratio $0.4: 1: 1.89: 3.84 ; 28$ day cube strength $540 \mathrm{kp} / \mathrm{cm}^{2}$. Mix 4: water-cement-sand-gravel $0.39: 1: 1.9: 3.85,28$ day cube strength $570 \mathrm{kp} / \mathrm{cm}^{2}$. Superplasticizer $1.5 \%$ was used.

\section{REFERENCES}

[1] Bažant Z. P., Panula L. - Practical prediction of timedependent deformations of concrete, Materials and Structures, Parts I and II: Vol. 11, No. 65, 1978, pp. 307-328; Parts III and IV: Vol. 11, No. 66, 1978, pp. 415-434; Parts V and VI: Vol. 12, No. 69, 1979, pp. 169-183.

[2] Bažant Z. P., PAnula L. - Creep and shrinkage characterization for analyzing prestressed concrete structures, $\mathrm{PCl}$ Journal/May-June 1980, pp. 86-122.

[3] Bažant Z. P. and Panula L. - New model for practical prediction of creep and shrinkage, Publication SP-76, American Concrete Institute, 1982, p. 7-23.

[4] BAŽANT Z. P., ZевiCH S. - Statistical linear regression analysis of prediction models for concrete creep and shrinkage, Cement and Concrete Research, Vol. 13, 1983, pp. 869-876.

[5] Ngab A. S., Nilson A. H., Slate F. O. - Behavior of high-strength concrete under sustained compressive stress, Report No. 80-2, February 1980, Department of Structural Engineering, Cornell University, Ithaca, New York. 
[6] Ngab A. S., Nilson A. H., Slate F. O. - Shrinkage and creep of high strength concrete, Journal of the American Concrete Institute, July-August 1981, No. 4, Proceedings, Vol. 78, pp. 255-261.
[7] Collepardi M., Corradi M., Valente M., Low slump loss super-plasticized concrete laboratory and field tests on rheoplastic concrete, Research and Development Laboratories MAC, Mediterranea Additivi Cemento, Treviso, Italy.

\section{RESUME}

Prévision pratique du fluage et du retrait de béton à haute résistance. - On a étendu au béton à haute résistance le modèle élaboré précédemment pour le béton de résistance normale. On s'est aperçu qu'il suffisait d'apporter dans les formules de fluage au séchage une légère correction pour l'effet de résistance du béton. Les formules de fluage de base et de retrait ne nécessitent pas d'adaptation. On compare le modèle de prévision avec les données d'essais récemment obtenues pour le fluage et le retrait par Ngab, Nilson et Slate, ainsi que par Collepardi, Corradi et Valente, et on constate une concordance satisfaisante. Le coefficient de variation des écarts par rapport aux données d'essai n'est pas plus important que pour l'échelle de résistance normale. Cependant, les données actuelles sont assez limitées, il serait donc souhaitable de continuer les essais. 